\title{
Considerations that may influence the result of trials assessing tensile strength in experimental surgery ${ }^{1}$
}

\author{
Considerações que podem influir no resultado de pesquisas que avaliam a resistência \\ tênsil em cirurgia experimental
}

Lucas Félix Rossi², Renata Ribeiro Ramos², Jorge Bins Ely ${ }^{3}$, Darlan de Medeiros Kestering ${ }^{4}$, Marly da Silveira Soldi ${ }^{5}$, Sandro Polidoro Berni Brum ${ }^{6}$, Armando José d`Acampora ${ }^{7}$

1. Research performed at Santa Catarina South University (UNISUL), Experimental Surgery and Operative Technique Laboratory, Federal University of Santa Catarina (UFSC), Brazil.

2. Graduate Student of Medicine, UNISUL, Santa Catarina, Brazil.

3. PhD, Associate Professor, Surgeon in Chief Plastic Surgery, University Hospital, UFSC, Santa Catarina, Brazil.

4. Master, Full Professor, Experimental Surgery and Operative Technique Division, UNISUL, Santa Catarina, Brazil.

5. Master in Chemistry, UFSC, Santa Catarina, Brazil.

6. Master, Full Professor, Experimental Surgery and Operative Technique Division, UNISUL, Santa Catarina, Brazil.

7. PhD, Associate Professor, Surgeon in Chief, General Surgery at Florianópolis Hospital, Brazil.

\begin{abstract}
Purpose: To provide information gathered upon the execution of trials assessing tensile strength in experimental surgeries. Methods: Descriptive study considering details on the execution of trials assessing tensile strength in experimental surgery. Results: The analysis of the rupture force in a mechanical test machine is an adequate technique since it provides precise and quick results. It can, undoubtedly, be developed in this context of the eminently mechanical analysis of trials on experimental surgery. Conclusion: The utilization of a mechanical test machine is a useful tool in the assessment of materials' strength, providing accurate results. Nevertheless the trials must be well structured analyzing the multiple variables so as to attain a pattern of constant reproducibility and to provide the necessary reliability.
\end{abstract}

Key words: Surgery. Experimental Development. Animal Experimentation. Tensile Strength.

\section{RESUMO}

Objetivo: Fornecer informações advindas da experiência com a realização de trabalhos que avaliam a resistência tênsil em cirurgia experimental. Métodos: Estudo descritivo considerando detalhes da execução de trabalhos que avaliam a resistência tênsil em cirurgia experimental. Resultados: A análise da força de ruptura em máquina de ensaios mecânicos é uma técnica apropriada e que fornece resultados precisos e rápidos. Pode ser desenvolvida neste contexto da análise eminentemente mecânica de estudos em cirurgia experimental. Conclusão: A utilização da máquina de ensaios mecânicos é uma ferramenta útil na avaliação da resistência de materiais fornecendo resultados precisos. Entretanto os trabalhos devem ser estruturados analisando múltiplas variáveis para alcançar um padrão de reprodutibilidade constante e trazer a confiabilidade necessária ao estudo.

Descritores: Cirurgia. Desenvolvimento Experimental. Experimentação Animal. Resistência à Tração. 


\section{Introduction}

Nowadays there is great apparent effort towards the conduction of experimental surgery trials analyzing tensile strength, leading to the publication of numerous articles in the last few years, analyzing several different aspects. Not always can such experiments be reproduced, given the difficulty in attaining some details as to the machines used to measure tensile strength. This article was originated based on the experience acquired upon the development and production of two experimental trials assessing tensile strength in the abdominal wall of rats following synthesis with synthetic meshes ${ }^{1}$ and surgical wires ${ }^{2}$, and the observation of the difficulties and failures with some of the specimens. The observations thereof are described herein. A few concepts must be better explained so as to provide a reasonable understanding of the studies approaching this line of research. Metrology, in general, is a science that involves every theoretical and practical measurementrelated aspect, whatever the uncertainty may be, in any field of science or technology ${ }^{3}$. Metrology is divided into three areas: legal, scientific and industrial metrology. Legal Metrology is understood in the international consensus as "the division of metrology which deals with measurement units, methods and instruments according to mandatory technical and legal requirements, in which incorrect measurements may lead to undesirable risks to individuals or to society" 4. The determination of the mechanical property of materials is obtained by means of mechanical tests, conducted on the product alone or on specimens of specified dimensions and shapes ${ }^{3}$. The tensile strength test consists of submitting the material to traction that tends to stretch it until it ruptures. The traction or load is measured in the machine test itself. In the tensile strength test the specimen is deformed through elongation, until it ruptures. Such tests allow us to know how materials react to traction forces, what traction limits they support and when they finally rupture. The force is applied in the longitudinal axis and is called axial force, which is perpendicular to the specimen's cross section. The application of an axial force of traction on a trapped specimen produces a deformation, that is, an increase in its length with a decrease in the width area. Such an increase in length is called elongation ${ }^{5}$.

\section{Purpose}

To publish data resulting from the experiment with the conduction of trials assessing tensile strength in experimental surgery.

\section{Methods}

Tensile strength studies will always comprise an important experimental tool to be used on an ongoing basis, reflecting the effect of multiple and complex variables which may be imposed by one or several experimental conditions ${ }^{6}$. It is agreed that as the generated variables can be perceived in loco, some of them are fully predictable and can be somewhat controlled, whereas others are not and remain out of control. These are called dependent and independent variables. Therefore, this article has been generated according to the perceptions that usually take place during an experiment that uses a tensile strength test, the description of which has not been found thoroughly described in the literature, yet are regarded as important by this group of researchers in the aspects which are described next. A pilot project is considered to be of vital importance and fully indispensable, since tensile strength studies may provide several biases in the results, which keeps the researcher from knowing the actual result. Such biases in the results take place upon data collection, since the variables are present in the performance of the tests itself. A computer-guided universal test machine was used in the tests (Figure 1). Nowadays these test machines are computerized and high-tech, increasing reliability in the results obtained. In the past, much less complex devices were used, as described by Crawford, Brains e Ketcham $^{6}$, whose proposed results and conclusions cannot be discarded. When the trial was initiated, the focus was totally towards investigating the tensile strength of laboratory animals' abdominal wall, seeking an exchange of knowledge between medical sciences and exact sciences, Physics most specifically. A few Physics' concepts must be expanded so as to allow a good understanding of the article. When discussing about tensile strength tests, it is understood that a magnitude is needed to measure the rupture point and such magnitude is called force, which will be the assessing unit of the force utilized to achieve the rupture of the material under study. The physical unit used to quantify force according to the International System of Units is Newton (N). Other systems' units of force which may be used are: dina (din), Kilogram-force (kgf), poundforce (Lb or lbf), and the equivalency between the units is the following: $1 \mathrm{~N}=10^{5} \mathrm{~d}=1 \mathrm{kgf}=9,80665 \mathrm{~N}$. In experimental trials there is the need to obtain what is called a specimen, which, in this trial, was the abdominal wall of

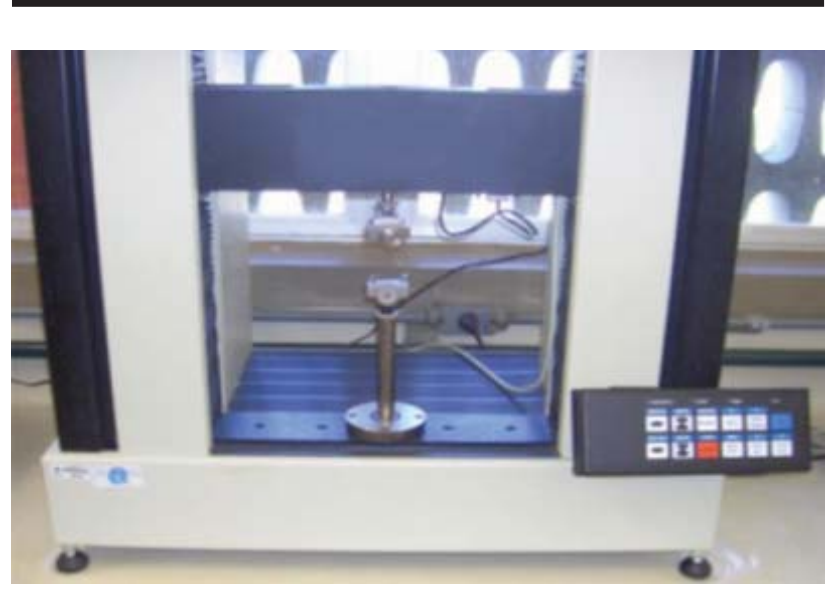

FIGURE 1 - Computerized mechanical test machine used in the tensile strength tests 
Wistar rats. The first aspect to be considered is the quality of the material used for analysis. Usually, the specimen in experimental surgery is represented by organic matter such as, for instance, fragments of animal species. The problem related to the specimen will be the fixation of the material (specimen) to the intrument used to allow the obtention of the results in Newtons. Such fixation is of utmost importance for the success of the test. Most errors have to do with the choice of the clamp used to provide the fixation of the material, this being the main aspect to be considered, since the wrong choice may provide inconsistent data which will certainly lead to error during the interpretation of results. When specimens are composed of organic matter (animal tissue), they must preferably be fixed with grooved clamps, as shown in Figure 2. The use of clamps with a non-grooved (smooth) surface causes a crushing of the specimen, as excessive force is applied in the fixation area, thus causing deformation and distortion. Besides, when the mechanical test is performed, smooth clamps will produce a cutting effect on the tissue, causing the material to be sectioned on the fixation spot. This will make it impossible to obtain data from this specimen, leading to the loss of the test (Figure 3). This is one of the most frequent errors: the incorrect choice of the specimen's fixation device, leading to loss of time and to the need to start the experiment over again in order to obtain reliable and scientifically consistent results. The force to be applied on the specimen must be isolated and, for that to be viable, the area submitted to the traction test must be as small as possible, while still meeting the standards established according to the trial objectives. Thus, when proper fixation is achieved with the clamps, keeping the specimen in place when traction is first applied, the test itself can be carried out and results can be collected. With the proper fixation it is also possible to apply an axial force in the center of the specimen, as demonstrated in Figure 4. The distance between the clamps must also be watched, and must be minimally kept for the test to be performed accordingly. Adjusting the clamps this way we manage to isolate the force in the desired area, thus allowing traction to be applied exactly where on the spot to be analyzed (Figure 4). After the preparation process, the test is started, producing a force contrary to the specimen. During the time in which the machine is applying the force to the specimen, an elongation of the material takes place, until it finally ruptures (Figure 5). In some circumstances in which the specimen does not rupture, we may use the maximum force applied by the machine, after which there will be no more increase of force value. This can be done provided that the material fixation has been done properly. All previously discussed information are useless if we do not worry about the calibration of the instrument used. All measuring equipment must be calibrated using measuring standards that are traceable to international or national measuring standards ${ }^{7}$. In this context, it is necessary to define the ideal load cell to be used, as it will become the most important part of the test machine.

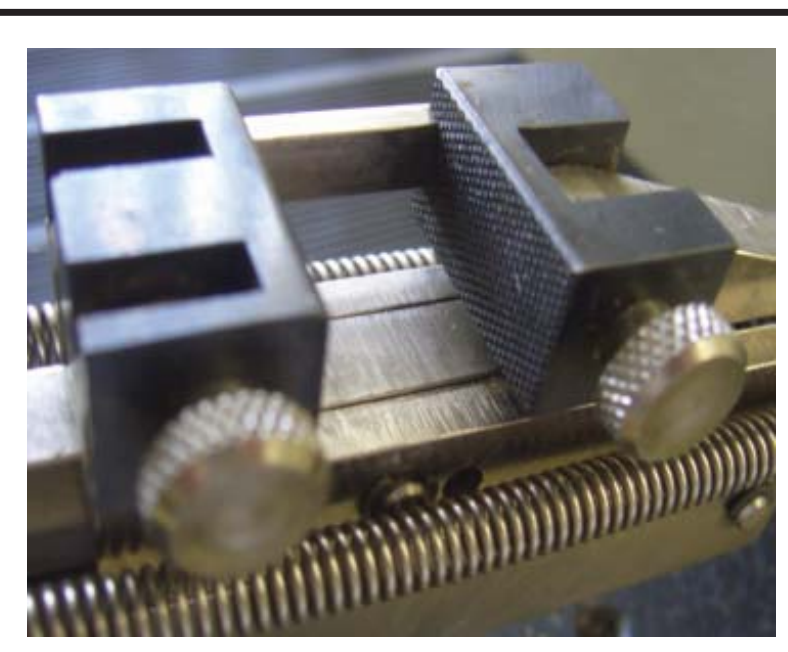

FIGURE 2 - Detail of clamp with biting grooves in the fixation area. This type of clamp provides the ideal constant pressure for experimental surgery trials

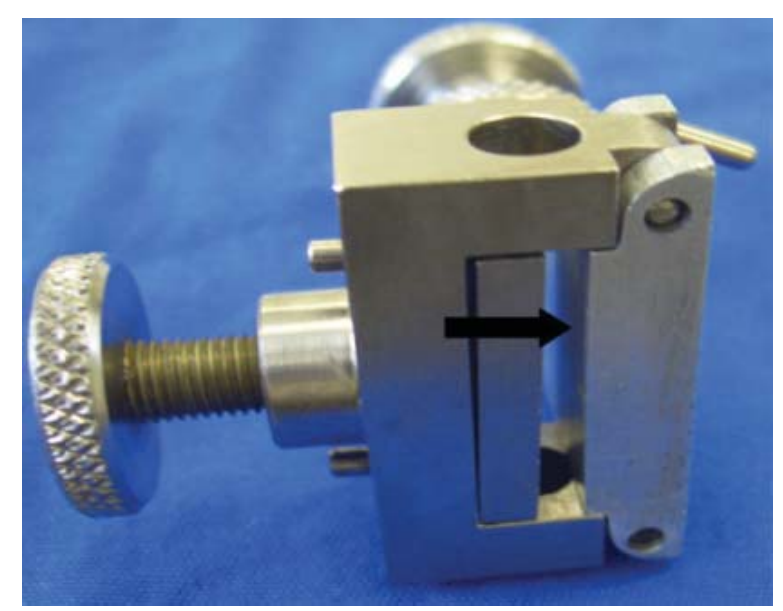

FIGURE 3 - Clamp with smooth fixation surface. It is considered to be inadequate for the fixation of organic material

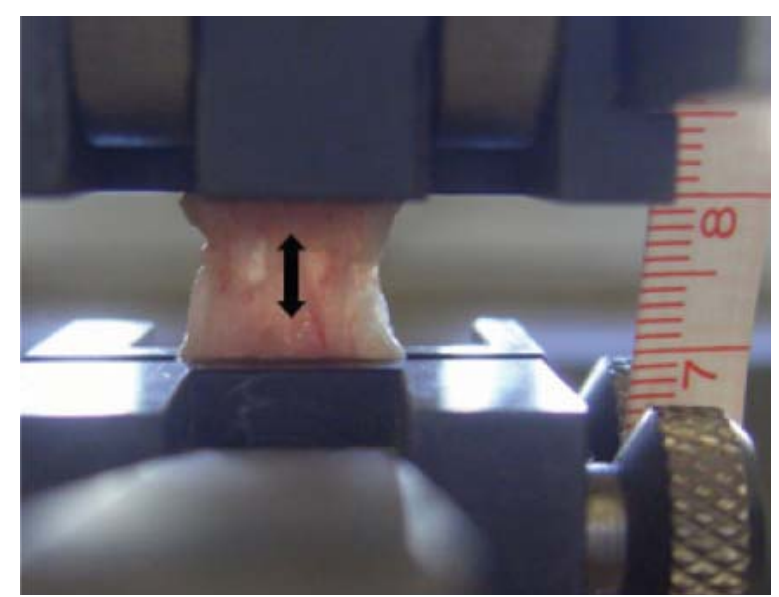

FIGURE 4 - Correct form of specimen fixation on the clamps. The arrow shows that the traction force will be applied perpendicularly to the center of the specimen. Note the small distance $(1 \mathrm{~cm})$ between the clamps 


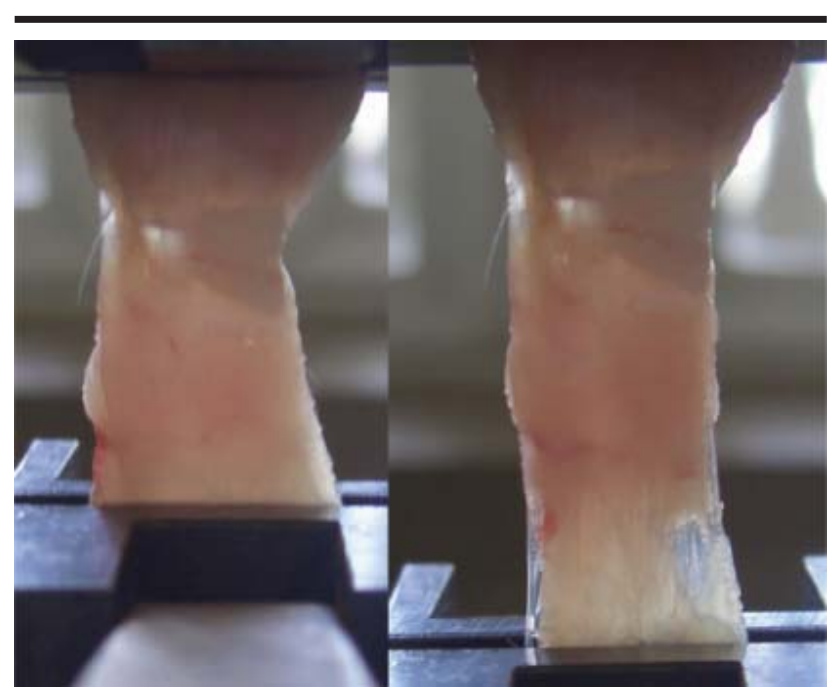

FIGURE 5 - Process of specimen elongation when submitted to traction test

The load cell is a mechanical/electronic device which measures deformation and the consequent tension and force. Traction analyses in experimental surgery usually utilize organic matter, so there is no need to apply great forces. Thus, we used the load cell with the capacity of $50 \mathrm{~N}$, which presents a reading resolution of $0.01 \mathrm{~N}$ and is recommended for tests in the range of 1 to $50 \mathrm{~N}$. The scope of this article is not to review the extensive system of equipment calibration, however we must bear in mind that the measurements must not allow significant error and that INMETRO must be part of the equipment metrological control process. Finally, it is important to highlight that the rupture force analysis in mechanical test machines in an appropriate technique which allows precise and quick results. It can, undoubtedly, be developed in this context of the eminently mechanical analysis of trials in experimental surgery.

\section{Conclusion}

Tensile strength analysis using a mechanical test machine is an appropriate technique which allows precise and quick results. Nevertheless, trials must be wellstructured taking into account multiple variables so as to achieve a constant pattern of reproducibility and to provide the necessary reliability.

\section{References}

1. d'Acampora AJ, Kestering AM, Soldi MS, Rossi LF. Experimental study comparing the tensile strength of different surgical meshes following aponeuroticmuscle deformity synthesis on Wistar rats. Acta Cir Bras. 2007;;22(1):47-52. Available from <URL: $\underline{\text { http:// }}$ www.scielo.br/acb>.

2. d'Acampora AJ, Kestering AM, Soldi MS, Ramos RR, Rossi LF. Estudo da resistência tênsil da parede abdominal após síntese de laparotomia usando três tipos de fios cirúrgicos em ratos Wistar [Monografia]. Tubarão: Universidade do Sul de Santa Catarina (UNISUL); 2007.

3. Queiroz MA Metrologia: um retorno muito além do financeiro. 2005 Ago [capturado 2006 Out 24]; [9 telas]. Disponível em: <http://www.emic.com.br/artigos. php?id_artigo=127\&categoria=outros\&lang $=16>$

4. Informações básicas sobre ensaio de tração. 2005 Jun [capturado 2006 Out 24]; [4 telas]. Disponível em: $<$ http://www.emic.com.br/artigos.php?id_artigo=123\& $\underline{\text { categoria=tecnicos\&lang }=16>}$

5. OIML Introduction and Presentation. Home page da Organização Internacional de Metrologia Legal [capturado 2006 Out 24]; [1 tela]. Disponível em: <http://www.oiml.org/information/presentation.html>

6. Crawford DT, Brais JW, Ketcham AS. A standard model for tensiometric studies. J Surg Res. 1965;5(6):265-9.

7. Menezes CIC, Salles MT, Silva MAS. Uma ferramenta para melhora da qualidade dos instrumentos da área da saúde. Metrologia para a Vida; 2003 Set 1-5; Recife, Pernambuco. Brasil. Sociedade Brasileira de Metrologia.

\section{Correspondência:}

Lucas Félix Rossi

Rua Dr. Montauri, 1478/302

95020-190 Caxias do Sul - RS Brazil

felixrossi@brturbo.com.br
Conflict of interest: none Financial source: none

Received: April 10, 2007

Review: June 12, 2007

Accepted: July 18, 2007

\section{How to cite this article:}

Rossi LF, Ramos RR, Ely JB, Kestering DM, Soldi MS, Brum SPB, d’Acampora AJ. Considerations that may influence the result of trials assessing tensile strength in experimental surgery. Acta Cir Bras. [serial on the Internet] 2007 NovDec;22(6). Available from URL: http://www.scielo.br/acb 